A. Mishchenko

\title{
NONCONTACT METHOD OF THE ARTILLERY AMMUNITION CHARGES INTERNAL TEMPERATURE DETERMINATION AND MODELS FOR ITS ERRORS
}

In the article analyzed the accuracy of noncontact artillery ammunition charges temperature measurement method, based on measuring the temperature of surfaces, mathematical models of the measurement errors in input variables impact on the error of cooling (heating) rate and charge temperature.

Keywords: ballistic preparation, temperature measurement, accuracy.

УДК 616-093

О. А. Никитюк ${ }^{1}$, д.с.-Г.н., В. М. Новіков ${ }^{2}$, д.ф.-м.н.

${ }^{1}$ Національний медичний університет ім. О. О. Богомольия, м. Київ

${ }^{2}$ Інститут підвищення кваліфікації фахівців в галузі технічного регулювання та споживчої політики Одеської державної академії технічного регулювання та якості, м. Київ

\section{АНАЛІЗУВАННЯ ВИМОГ ДО ЯКОСТІ ТА КОМПЕТЕНТНОСТІ МЕДИЧНИХ (КЛІНІКО-ДІАГНОСТИЧНИХ) ЛАБОРАТОРІЙ}

В статті продовжено аналіз сучасних вимог до якості та компетентності медичних (клінікодіагностичних) лабораторій, визначених стандартом ДСТУ EN ISO 15189:2015 [1] стосовно взаємодії прочесів в лабораторії та індикаторів якості основних прочесів.

Запропонований варіант схеми взаємодії основних прочесів для медичних лабораторій.

Ключові слова: компетентність, медичні лабораторії, системи управління якістю.

Впровадження міжнародно-визнаних вимог до компетентності в практику роботи медичних (клініко-діагностичних) лабораторій України залишається актуальною задачею для фахівців галузі.

На фоні вже наявного сучасного, гармонізованого 3 європейськими аналогами, європейськими, зокрема нового Закону України «Про метрологію та метрологічну діяльність» [2], де єдиним інструментом оцінювання компетентності органів $з$ оцінки відповідності, в т. ч. і медичних лабораторій, $є$ акредитація (а не атестація на право виконання метрологічних робіт, як це було раніше), поки що в Україні, на жаль, не маємо жодної акредитованої медичної лабораторії.

Стає зрозумілим, що медичним лабораторіям бракує методичної підтримки для впровадження сучасних вимог до якості і компетентності.

Метою даної роботи $\epsilon$ продовження роботи [3] 3 аналізування вимог [1], шляхом їх порівняння $з$ широковідомими вимогами до компетентності випробувальних і калібрувальних лабораторій (стандарт ДСТУ ISO/IEC 17025 [4], досвід впровадження якого в Україні значний [5]).

В попередній роботі [3] нами розпочато порівняльний аналіз вимог [1] та [4], результати якого дозволяють фахівцям медичних лабораторій (при підготовці до акредитації та впровадженні положень [1] в практику своєї роботи) спиратися на наявний багаторічний досвід акре- дитації лабораторій випробувальних, що був накопичений за час впровадження вимог до їх компетентності [5].

Основними результатами проведеної нами роботи слід вважати висновок про те, що базові вимоги [1] формуються, виходячи із положень [4], що спрощує підготовку до акредитації медичних лабораторій, вважаючи на можливість використання наявного досвіду та методичних рекомендацій.

Особливі ж технічні вимоги [1] та особливі вимоги моделі системи управління, в порівнянні 3 [4], напевне, визначаються двома наступними факторами.

Модель системи управління якістю в [1] більш сучасна, так як базується на положеннях відомого стандарту ISO 9001 версії 2008 р., (на відміну від [4], що включає положення ISO 9001 версії 2000 р.).

Саме цей фактор визначає основні відмінності сучасних вимог до систем управління якістю для медичних (клініко-діагностичних) i випробувальних лабораторій.

Стосовно відмінностей технічних вимог до компетентності лабораторій стандартів [1] та [4], то вони, на наш погляд, сформовані, виходячи із основної відмінності природи та походження зразків (проб), призначення результатів випробувань (досліджень). А саме, головна відмінність медичної лабораторії полягає в тому, що проба (зразок) береться від тіла живої людини. 
Для випробувальної (калібрувальної) лабораторії зразок (проба), наприклад, є:

- зразок засобу вимірювальної техніки (калібрувальна лабораторія);

- проба (зразок) тваринного походження (ветеринарні лабораторії).

Другою фундаментальною відмінністю медичної (клініко-діагностичної) лабораторії, що акредитується (підтверджує компетентність згідно вимог [1]) від інших, які акредитуються чи підтверджують компетентність за вимогами [4] $\mathrm{e}$ призначення результатів випробувань (досліджень).

Результати досліджень проби (зразка) медичної лабораторії призначені для діагностування (оцінки стану здоров'я), лікування, профілактики, тобто так чи інакше результати прямо пов'язані із суттєвими ризиками для життя людини.

Результати ж випробувань інших лабораторій хоча і можуть бути пов'язані із ризиками щодо безпечності людини (харчові, ветеринарні лабораторії, лабораторії із випробувань параметрів безпечності), але очевидно не пов'язані із діагностуванням і параметрами стану здоров'я людини.

Криміналістичні лабораторії підтверджують свою компетентність за вимогами [4], як і будьякі інші випробувальні лабораторії, так як мають справу із зразками виробів, пробами матеріалів та пробами від тіла мертвої людини, або живої, але результати досліджень таких проб не мають на меті діагностування, і не пов'язані із станом здоров'я, а пов'язані із визначенням порівняльних характеристик аналогічних проб інших людей та визначення фізико-хімічних, біологічних характеристик проби (зразка).

Перейдемо до аналізування відмінностей вимог [1] та [4] системного характеру.

Аналогічно [4], в [1] від лабораторії вимагається розробити, задокументувати, впровадити та підтримувати системи управління якістю, постійно підвищувати іiі результативність.

Але в [1], є особливі вимоги стосовно необхідності визначення послідовності і взаємодії процесів системи, критеріїв та методів, необхідних для функціонування процесів (р. 4.2.1), показників (індикаторів) якості для моніторингу та оцінювання результативності усіх процесів лабораторії (р. 4.14.7), чого від випробувальних лабораторій в [4] не вимагається.

Попередній позитивний досвід застосування відомого методу «життєвих циклів» до реалізації вимог щодо компетентності [4] в випробувальних лабораторіях (див. Наприклад, [5]) дозволяє запропонувати наступний варіант впровадження специфічних вимог вищезазначених р. 4.2.1 та 4.14.7 [1] в практику роботи медичних лабораторій.

Стосовно описання послідовності і взаємодії процесів в лабораторії. Стандартом [1] (по аналогії з [4]), чітко визначено, які саме процеси в лабораторії мають бути задокументовані у вигляді процедур (методик) системи управління якістю та які дані мають зберігатися в лабораторії в якості доказів виконання зазначених процедур.

Звісно, лабораторія може документувати і додаткові процеси, обов'язковість документування яких не зазначена в [1], чи [4].

Діяльність будь-якої організації направлена на досягнення запланованого організацією результату.

Коли ми кажемо про лабораторію, то результатом іiі діяльності $\epsilon$ отримання протоколів (звітів) про випробування (дослідження).

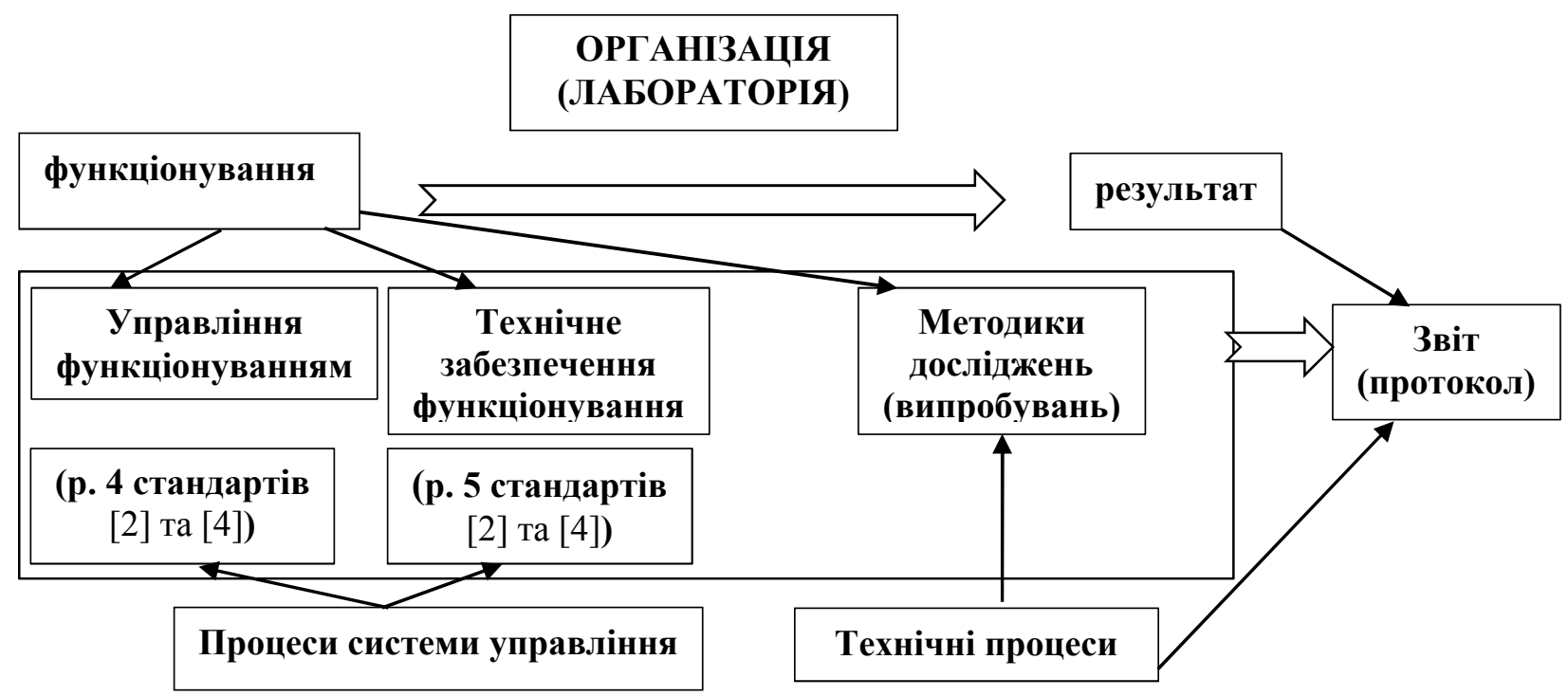

Рисунок 1 - Загальна схема функціонування лабораторії 
Звіти чи протоколи (тобто результати роботи) отримуються внаслідок реалізації лабораторних методик. В свою чергу їх реалізація завжди проходить в рамках певної системи управління роботою та технічного забезпечення (як це визначено відповідними вимогами розділів 4 та 5 стандартів [1] та [4]) (див. рис. 1).

Отже, як бачимо із рис. 1, всі процеси в лабораторії - це процеси системи управління (вимоги до яких визначені розділами 4 та 5 стандартів [1], [4]), або процеси технічні (методики проведення досліджень, випробувань та звітування про результати). Вимоги до останніх описані не в стандартах [1], [4], а в методиках проведення випробувань (досліджень), описаннях до обладнання та ін. Технічній документації лабораторії, документах регуляторних органів.

Можна вважати, що ці процеси не взаємодіють між собою, а функціонують паралельно.

Аналізування вимог [1] та [4] показує , що в лабораторії всі процеси системи управління можна умовно (за ознакою послідовності взаємодії) розподілити на 2 категорії.

До першої категорії відносимо такі процеси, вихідні дані кожного 3 яких є вхідними даними наступного, тобто процеси, які взаємодіють послідовно в рамках циклу Демінга. Такі процеси можна назвати процесами управління функціонуванням. Та процеси, які взаємодіють не послідовно, а паралельно і направлені на забезпечення управління функціонуванням.

Приклад (варіант) схеми взаємодії процесів в лабораторії, побудований на логіці, викладені нами вище, зображений на рис. 2.

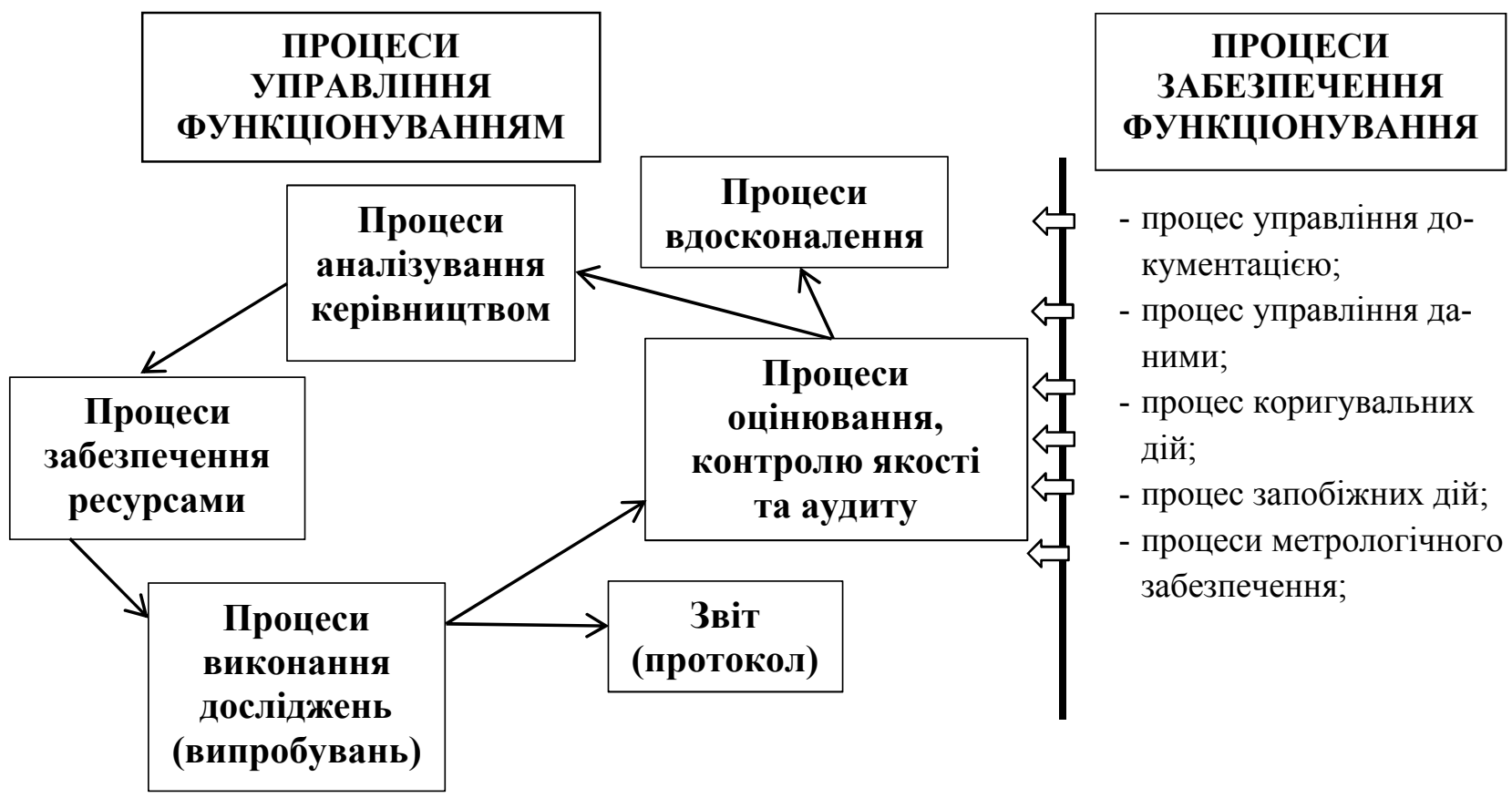

Рисунок 2 - Запропонований варіант узагальненої схеми взаємодії процесів в лабораторії

Запропонована узагальнена схема взаємодії процесів в лабораторії (рис. 2) просто конкретизується в залежності від специфіки діяльності медичної лабораторії.

Процесами «паралельними» можна вважати процеси забезпечення функціонування (за вимогами [1] це процеси, які мають бути регламентовані, наприклад, процедурами управління документацією, управління даними та ін.).

Також паралельними процесами слід вважати i процеси виконання кожної із методик досліджень.

Усі інші процеси системи управління взаємодіють послідовно, як видно із рис. 1.

Висновки

1. Продовжено аналізування вимог стандар- ту [1] в порівнянні з [4], результати якого мають полегшити підготовку до акредитації медичних лабораторій, спираючись на використання вже наявного методичного досвіду реалізації положень [4] в лабораторіях випробувальних.

2. За результатами досліджень запропонований варіант узагальненої схеми взаємодії процесів та проведена класифікація основних процесів, відповідно до вимог [1] стосовно системи управління в медичних лабораторіях.

\section{Список використаних джерел}

1. ДСТУ EN ISO 15189:2015. Медичні лабораторії. Вимоги до якості та компетентності. Затверджений наказом ДП «УкрНДНЦ» № 61 від 
22.06.2015p

2. Закон України «Про метрологію та метрологічну діяльність» із змінами, внесеними відповідно до Закону № 124-VIII від 15.01.2015.

3. Новіков В. М. Аналізування вимог до компетентності клініко-діагностичних лабораторій / В. М. Новіков // Збірник наукових праць ОДАТРЯ. - Одеса, 2015. - Вип. 2(7). - С. $66-68$.

4. ДСТУ ISO/IEC 17025:2006. Загальні вимоги до компетентності випробувальних та калібрувальних лабораторій - [Чинний від 2007-
07-01]. - К.: Держспоживстандарт України, 2006.

- 27 с. - (Національний стандарт України).

5. Новіков В. М., Никитюк О. А., Новіков В. В. Основи компетентності лабораторій. Навчальний посібник // Під ред. Д. ф.-м. н. проф. Новікова. - К.: Фавор, 2013. - 268 с.

Надійшла до редакиії 31.10.2016

Рецензент: д.т.н., проф. Коломієць Л. В., Одеська державна академія технічного регулювання та якості, м. Одеса.

\section{А. А. Никитюк, д.с.-х.н., В. Н. Новиков, д.ф.-м.н.}

\section{АНАЛИЗИРОВАНИЕ ТРЕБОВАНИЙ К КОМПЕТЕНТНОСТИ КЛИНИКО-ДИАГНОСТИЧЕСКИХ ЛАБОРАТОРИЙ}

В статье продолжен анализ современных требований к качеству и компетентности медииинских (клинико-диагностических) лабораторий, определенных стандартом ДСТУ EN ISO 15189:2015, касаемых взаимодействия процессов в лаборатории и индикаторов качества исполнения основных проиессов.

Ключевые слова: компетентность, медициские лаборатории, системы управления качеством.

A. A. Nykytyuk, DSc, V. N. Novikov, DSc

\section{AN ANALYSIS OF REQUIREMENTS IS TO COMPETENCE OF CLINICODIAGNOSTIC LABORATORIES}

In the article the analysis of modern requirements is conducted to the competence of medical (clinicodiagnostic) laboratories, certain the standard of DSTU EN ISO 15189:2015.

Grounded features of development of requirements to the competence in part of management of medical laboratory as compared to a laboratory proof-of-concept.

Keywords: competence, medical laboratories, control system by quality.

УДК 621.372 .54

\section{Г. Н. Ергиев, к.т.н.}

Одесская государственная академия технического регулирования и качества, г. Одесса

\section{СИНТЕЗ АКТИВНЫХ RС-ФИЛЬТРОВ С ПЬЕЗОЭЛЕКТРИЧЕСКИМИ РЕЗОНАТОРАМИ}

В статье предлагается метод синтеза фильтров с пьезоэлектрическими резонаторами, при котором реализачию сложных фильтров предполагается осуществлять на базе каскадноразвязанного включения типовых звеньев фиксированного порядка из некоторого базового набора. Аппроксимация, т.е. конструирование передаточной функиии фильтра производится методами оптимизации с учетом требований всех условий, как физической, так и схемной реализации. Приведен пример решения задачи аппроксимации для выбранного типа звена с различными требованиями $\kappa$ АЧХ фильтра.

Ключевые слова: активные фильтры с пьезоэлектрическими резонаторами, аппроксимация АЧХметодами оптимизаиии, базовый набор звеньев, САПР.

Одной из актуальных задач при приборостроении является задача синтеза проектировании и разработке систем связи, высокоизбирательных частотных фильтров со радиосвязи, радиолокации, систем телеметрии, стабильными характеристиками, этим автоматического контроля и управления, техническим требованиям соответствуют схемы 